\title{
ASEAN and the EU amidst COVID-19: overcoming the self-fulfilling prophecy of realism
}

\author{
Frederick Kliem $^{1}$
}

Received: 16 July 2020 / Revised: 29 December 2020 / Accepted: 10 February 2021 / Published online: 13 March 2021

(C) The Author(s), under exclusive licence to Springer-Verlag GmbH Germany, part of Springer Nature 2021

\begin{abstract}
The coronavirus disease 2019 (COVID-19) pandemic is one of the greatest challenges of our lifetime. Quite appropriately, the pandemic has been declared a non-traditional security (NTS) threat in many countries in Europe and Asia. Beyond its detrimental effect on public health, COVID-19 is testing the international resolve to cooperate and represents a particularly tricky challenge to regionalism. Due to the nature of pandemics, regional pandemic management is imperative. However, the two most successful regional organisations, the European Union (EU) and the Association of Southeast Asian Nations (ASEAN), have not been able to match the resolve of their individual member states, and there is a substantial gap between timely and robust national pandemic management and inadequacy at the regional level. This is a paradox that merits further investigation. To what extent and why diverged early national and early regional responses to COVID-19? This article identifies a causal relationship between robust national pandemic management as a result of early securitisation and ensuing paralysis on regional level, a process which I call the 'selffulfilling prophecy of realism' - a vicious cycle of national self-help responses paralysing regional cooperation. This article contributes early to the impact of COVID-19 on regionalism by analysing EU and ASEAN pandemic management efforts, investigating what has hindered or facilitated successful regional cooperation and identifying room for meaningful interregionalism.
\end{abstract}

\section{Introduction}

The coronavirus disease 2019 (COVID-19) pandemic, caused by severe acute respiratory syndrome coronavirus 2 (SARS-CoV-2), is one of the greatest challenges of our lifetime. Quite appropriately, the pandemic has been declared a non-traditional security

Frederick Kliem

isfkliem@ntu.edu.sg

1 Centre for Multilateralism Studies, S. Rajaratnam School of International Studies, Nanyang Technological University, 50 Nanyang Ave, Singapore 639798, Singapore 
(NTS) threat in many countries in Europe and Asia. COVID-19 is not only threatening individual health and human security and causing economic devastation but it is also testing the international resolve to cooperate. While both great powers, China and the United States (U.S.), have hitherto failed to provide global leadership, the World Health Organisation (WHO) is, at best, a supporting actor, and even the European Union (EU) and the Association of Southeast Asian Nations (ASEAN) are struggling with outbreaks of nationalism and unilateral knee-jerk reactions across their membership.

For several reasons, the EU and ASEAN are the most promising case studies to assess the early effect of COVID-19 on institutionalised regionalism. Both Europe and Southeast Asia have been hit particularly hard by the COVID-19 pandemic, and both their regional organisations have been chastised for sluggish and insufficient early crisis responses. Indeed, several months into the global outbreak, it appeared as though COVID-19 may become the greatest challenge the EU had ever faced. Likewise, it remains unclear whether ASEAN will be able to muster an appropriate response despite plenty of goodwill. At the same time, the EU and ASEAN are widely recognised as the world's two most successful regional organisations (Dosch 2018) and if they fail to find effective answers to this crisis, it is unlikely that comparatively less integrated organisations elsewhere will. There are also strong inter-regional ties, which have been studied in great detail and offer a wealth of different perspectives (Yeo 2008; Börzel and Risse 2009; Jetschke and Murray 2012).

This article contributes early to the impact of COVID-19 on regionalism-a research area that will doubtlessly expand substantially in the years to come. It investigates how both organisations and their member states responded in the months following the global COVID-19 outbreak, what they have accomplished thus far, what hindered and facilitated successful regional cooperation, and whether there is any room for meaningful inter-regionalism. I identify a substantial gap between timely and robust national pandemic management and sluggish and inadequate regional responses. This is a paradox that merits investigation. To what extent and why diverged early national and early regional responses to COVID-19? The pandemic was securitised early on the national level across membership of both ASEAN and the EU. Timely national securitisation allowed for robust national responses, including lockdowns, border closures and travel bans, which helped to control the pandemic to some extent. However, the unintended consequence of robust national unilateralism has been potentially severe damage to regional cooperation. This article, therefore, identifies a causal relationship between robust national pandemic management and paralysis on regional level. Regionalism depends on cooperation, trust and communication, but the immediate selfhelp espoused by members of both regional organisations has initiated what I call the 'self-fulfilling prophecy of realism' - a vicious cycle of national self-help responses paralysing regional cooperation. As a result, COVID-19 proves to be a formidable challenge for regionalism and the future legitimacy of regional organisations.

Several months into the pandemic, both organisations are somewhat recovering from their initial COVID-19 paralysis. In particular, the EU has responded belatedly but remarkably comprehensive and meaningful. Brussels is defying the early pessimism it was surrounded by with pro-active mobilisation of material and financial support and coordination of member states' mutual assistance. While ASEAN has also become more pro-active as the pandemic progressed, the association quickly met its institutional limits and many agreements remain on paper. 
Nonetheless, COVID-19 represents a unique opportunity for both organisations to live-up to the ritualistically reoccurring promise of regional solidarity. For this to be possible, ASEAN and the EU must leverage existing mechanisms and instruments for intra- and inter-regional cooperation and re-build trust in regionalism. ASEAN cannot be expected to respond as coherently and effectively as the EU, but there are lessons to be learnt from the European response, which do not require the characteristically deep European institutionalisation and legalisation. Similarly, there is ample room for greater inter-regional cooperation and to leverage existing inter-regional instruments for policy exchange and lesson-drawing under the banner of increasing EU interest to be recognised as a contributor to non-traditional regional security in Asia.

If regionalism fails the COVID-19 test, we can expect a substantial set-back for both organisations and regionalism in general in terms of public support and the willingness by national elites to invest political capital in deeper integration. For the EU, failing to demonstrate pan-European solidarity will have disastrous consequences, including possible further exits, and even the collapse of the Eurozone. ASEAN would not collapse even in absolute COVID-apathy. But even ASEAN may suffer serious damage, as it is already struggling to prove its value-added to Southeast Asian citizens and external partners.

\section{The national securitisation of COVID-19 and the self-fulfilling prophecy of realism}

The COVID-19 pandemic represents one of the greatest global NTS threats. NTS definitions emphasise the importance of non-military sources threatening the wellbeing of nation states, their societies and communities, thereby widening the traditional interpretation of security beyond the state as main reference object for security (Caballero-Anthony 2018; Booth 2005). Such threats include environmental pollution, natural disasters and public health emergencies, such as the COVID-19 pandemic, which are detrimental to human security - a concept that recognises several additional dimensions of security beyond only direct physical violence. Human security generally aims to protect and enhance human freedoms and fulfilment from severe and pervasive threats and situations, including economic and food security (UN Commission on Human Security 2003).

The nature of pandemics, similar to many other NTS challenges, poses a multidimensional security threat, as their consequences cut across numerous other NTS challenges and severely threaten human security on multiple levels. COVID-19 already proves to be a challenge to public health at large, beyond the infected. COVID-19 overwhelms states' healthcare systems with potentially devastating consequences, as witnessed in Italy for example, where public healthcare crumbled under the pandemic (Horowitz 2020). It also affects the social and mental well-being of citizens as a result of public policy responses such as lockdowns and quarantines. Beyond health, COVID19 imperils the economic well-being of citizens, businesses and ultimately governments. Unemployment is rising, and the EU is predicting a 7.5\% recession (EU Commission 2020a) while ASEAN significantly lowered their growth prospects (ASEAN 2020a). The pandemic will cause the largest economic recession in decades, causing hardship for businesses and people, which may even put the integrity and 
legitimacy of the state at risk. Lastly, but not exhausting the full depth of negative spillover effects, pandemics harm economic transnationalism as for example supply chains are disrupted and migrant workers trapped in either sending or receiving country (Mügge 2016).

This leads to two preliminary conclusions: first, NTS threats are incredibly complex and second, they are inevitably transnational. This represents a direct dilemma for NTS management. Because of the immense complexity and serious spill-over effects across several domains of state and human security, national governments must react sharply and decisively to protect citizens' well-being. Such necessity for robust national action, however, may harm international cooperation, which is imperative due to the transboundary nature of NTS emergencies, such as pandemics. Hence, NTS issues represent a substantial challenge to regionalism.

Because of these potentially devastating effects of pandemics, health governance is high on national security agendas. Sufficient securitisation (Waever 1995) of COVID19 is imperative to change national political dynamics and re-prioritise policy agendas. Securitisation is essentially a speech act with the intended effect of heightened threat level perceptions pertaining to a particular issue. This creates an intersubjective understanding among all relevant stakeholders, including elite buy-in from media, civil society and epistemic communities, and thereby providing both ground and reason to deploy all means necessary to manage the threat. Securitisation can lead to a remarkably different array of policy options, for it allows governments to gain better executive control and concentrate larger amounts of resources.

In the case of COVID-19, substantial securitisation among national governments and civil society occurred as soon as the extent of the pandemic became obvious. ASEAN leaders entrusted the ASEAN defence establishments with information and best practice sharing (ASEAN 2020b). French President Macron and the French media declared war on COVID-19 (Momtaz 2020) and the British government mobilised its armed forces to support the civilian effort (UK Government 2020). Singapore made pandemic management a matter of national pride and unity and compared it to historical challenges of independence (SG United 2020). And while one may debate the appropriateness of the Vietnamese government's campaign to fight COVID-19 (Hayton and Tro Ly Ngheo 2020), it successful COVID-19 management is to a large extent the result of strong securitisation. The Vietnamese government revoked militaristic rhetoric from previous wars against the new 'foreign fatal threat', such as 'fighting this epidemic, means fighting the enemy', or 'every citizen is a soldier' and 'so long as there is a single invader left in our country, we have to wipe it all out'. This successfully reinforced the strong sense of national solidarity and galvanised many Vietnamese who take pride in their ability to unite in crisis and endure hardship (Nguyen and Ho 2020). Vietnam was thus legitimised to employ particularly robust policy responses, such as deploying substantial amounts of military personnel and equipment to close borders and enforce quarantines and lockdowns.

\section{Regional paralysis and the self-fulfilling prophecy of realism}

Both Europe and Southeast Asia are highly vulnerable to pandemics, owing to their deep interconnectedness in terms of integrated supply chains, trade and investment, tourism and people-to-people connectivity-intra- as well as inter-regionally. Such 
otherwise admirable linkages cascaded the virus across Southeast Asia and Europe. In both regions, integration is based on and accelerated by physical globalisation and connectivity, which has undoubtably contributed to stability and socio-economic development. Ironically, these fundamental pillars of regional integration are also what drives the spread of COVID-19 and what turned an epidemic into a pandemic. As briefly discussed above, like many NTS challenges, communicable infectious diseases are transboundary in nature and effective pandemic management must transcend the nation state. Pandemics inevitably make public health a matter of regional, not national concern. As COVID-19 has shown, international travel and trade cascades viruses across regions, and spikes in one country will lead to spikes elsewhere. This is first and foremost a function of physical globalisation, whereby tourism, supply chains and investment links, and economic, political and socio-cultural transnationalism transport viruses and communicable diseases across interconnected regions and even continents. This leads to the conclusion that NTS inevitably connects domestic public policy domains. More precisely, each ASEAN and EU member's individual public health system and governance becomes de facto a matter of national security across the whole of membership and even beyond. Likewise, European countries, for example, have a direct stake in China's health governance. The efficacy or lack thereof of Chinese health governance may lead to or prevent an acute NTS crisis in Europe, as the negative consequence of interconnectedness is internationalisation of problems. COVID-19 may have originated in China but has become a severe global problem. Consequentially, effective pandemic management must be put onto regional security agendas, too, and regional cooperation on managing and recovering from COVID-19 becomes a sine qua non for everyone's security and prosperity. Alas, timely national securitisation and robust responses had not been matched regionally, and both ASEAN and the EU have invited strong criticism (Herszenhorn and Wheaton 2020; ASEAN Today 2020).

Logically, it should precisely be the geographical regions where interstate cooperation to overcome a common transboundary challenge is most promising. And nowhere more so than in Europe and Southeast Asia, where decades-long processes of gradual regional integration have qualified absolute national sovereignty and socialised national policymakers into looking beyond narrow national self-interest to consider broader regional interests, too. Neoliberal institutionalists value international organisations as instruments to both facilitate and manage complex interdependence (Keohane and Nye 2001; Keohane and Martin 1995), while constructivists see great potential in mutual socialisation of national elites and norm diffusion processes across boundaries via regional organisations, both intra- and extra-murally (Finnemore and Sikkink 1998; Acharya 2009).

However, due to the risks inherent in the anarchic international system, neorealist international relations (IR) theory would predict that in times of crisis, states will resort to national and unilateral self-help with only their narrow national, instead of the regional interest in mind (Waltz 1979). Because international affairs are shaped only by the distribution of power within an anarchic international system, states prioritise relative gains over absolute gains, which makes meaningful cooperation difficult (Mearsheimer 1995). Thus, international institutions are at best epiphenomenal and neorealists ascribe only a marginal role for regional organisations such as ASEAN and the EU. According to realists, international cooperation comes easy in times of harmony, but COVID-19 demonstrated that the impact of institutions and organisations 
on state behaviour is rather limited when actually needed, i.e. when regional cooperation would achieve better outcomes than national unilateralism.

What such notions overlook, however, is the causal relationship between national self-help and regional institutional inadequacy. The inefficacy of regional organisations is both cause and consequence of robust national responses as a result of early national securitisation. Indeed, as realists would predict, initial national reactions to COVID-19 in Europe and Asia show that governments tend to follow their basic instinct and switch into full nationalist gear as soon as a security crisis emerges. Chaotic national self-help mechanisms instead of regionally conceived and coordinated COVID-19 management strategies were the result (Chong and Kliem 2020). In both the EU and ASEAN, multilateral cooperation came to a standstill as borders were closed and travel restricted.

Most governments in Southeast Asia initially implemented only partial and patchy travel restrictions for short-term visitors from China but were slow to extend this ban globally. Predictably, travellers and returning citizens from Europe and the U.S. caused a second wave of imported cases, while COVID-19 infections spread within local communities. As late as March, intra-ASEAN travel was still possible and even large cultural gatherings could still take place in some countries. The Indonesian government's lack of transparency and inadequate appreciation of the severity of the threat was matched by Cambodia's and led to a certain degree of complacency. As the pandemic spread, individual ASEAN countries took unilateral and uncoordinated action to stem the spread of the virus. For example, without consultation and with almost immediate effect, Malaysia announced a border closure on 16 March, including the causeway with Singapore - a critical supply route for goods and labour. This sparked chaotic mass movement of Malaysian cross-border workers to cross the border, collect their clothes and rush back to Singapore so that they could continue their employment in the city-state. It also left Singaporean employers struggling to secure temporary accommodation for their much needed and now stranded worker, and sparked fear and panic buying in vulnerable Singapore. Vietnam closed its Chinese border early on, and later unilaterally shut its ASEAN borders with Cambodia and Laos, which in turn prompted Cambodia to shut its own borders in retaliation (Khmer Times 2020).

Likewise, the EU Commission President von der Leyen called the COVID-19 response by EU member states a 'painful story' of 'only for me' responses and warned that too many EU members initially refused to 'share their umbrella' (EU Commission 2020b). Just like in Southeast Asia, EU members reacted in panic-mode as borders were unilaterally shut, de facto abandoning the de jure borderless Schengen area-a key pillar of European integration. Germany, for example, closed its borders with its southern and western neighbours immediately - a highly contentious violation of the spirit of a borderless Europe even during the 2015 refugee crisis.

Unilateral border closures, however, were only the most symbolic measure in the harshest return of national sovereignty the EU has ever witnessed. Once the extent of the pandemic became obvious, EU members almost immediately abandoned the most sacrosanct EU principles, such the four freedoms of movement (of people, goods, services and capital). And the most perfect rules-based international order the world has ever known became temporarily defunct, as the EU abandoned hard-won freedoms and jettisoned important regional rules, such as its competition law and fiscal discipline regulations. 
Most shocking to especially Italian citizens was the lack of European solidarity. Italy was hit early and particularly severe by COVID-19. In February, Rome activated the EU Civil Protection Mechanism (CPM) whereby EU members in need can appeal to other member states for crisis assistance. However, Rome's solidarity plea for medical support and equipment was met with silence for several weeks. Worth still, other countries went fully protectionist and decreed export bans on relevant medical goods, forsaking both European solidarity and the EU single market. Similarly, highly indebted, mostly southern EU countries hardest-hit by COVID-19 also requested European solidarity for post-COVID-19 economic recovery. In order to muster sufficient financial spending power, Italy and Spain proposed common Eurozone debt by issuing socalled Euro- or Coronabonds. Germany and other fiscally conservative northern EU net-contributor countries responded with a clear rejection of this idea (Kliem 2020a).

At the same time, both organisations were slow to respond despite the warnings of people like Richard Hatchett, former White House official and current CEO of the Coalition for Epidemic Preparedness and Innovations, at the World Economic Forum (WEF) in Davos in January, which numerous European and Southeast Asian delegations attended. Hatchett warned that COVID-19 had already morphed from China's problem into a global problem, and while it was well-known precisely what needed to be done in terms of international cooperation, there was a lack of political will to do so (WEF 2020). EU Commission President von der Leyen's speech at the same event did not mention the Coronavirus once; 3 days later, on 24 January, France became the first EU country to confirm a case of COVID-19. Yet, it took EU health ministers almost another 3 weeks to convene a first emergency meeting. And although COVID-19 had already been spreading in Asia, the initial outbreak in northern Italy in early March did not raise sufficient concern in Europe. The EU agency European Centre for Disease Control and Prevention (ECDC) expressed confidence that the situation in Italy was under control. Individual EU countries were deemed well-prepared to identify cases and treat patients nationally should the need arise. Only on 2 March did the ECDC elevate the risk of EU-wide infections to 'moderate to high' (ECDC 2020). At that time, many Europeans had just returned from ski vacations and large Carnival celebrations, which were later identified as multiple COVID-19 clusters (e.g. the Austrian ski resort Ischgl) from where the disease spread around Europe and globally.

Ten days prior to the WEF, on 13 January, Thailand had already confirmed its first case, the first country to do so outside China. Singapore and Vietnam confirmed their first cases on 23 January, Malaysia on the 25th. By late March, all ASEAN countries had confirmed cases, most of which were imported from East Asia. The first ASEAN Senior Health Officials Meeting on ASEAN COVID-19 cooperation took place on 13 March, the first Health Ministers' Meeting on COVID-19 as late as 6 April and the first leaders' meeting a week later. And despite plenty of statements on ASEAN solidarity, there was very little coordinated action on the ground.

The more ASEAN and EU member states, in particular the larger ones, chose to be complacent, or acted unilaterally with their narrow and immediate self-interest in mind, in some cases even contrary to the common good, the less likely a concerted regional response. Since there is no obvious collective action problem, it can be surmised that governments were acting unilaterally in anticipation of the absence of concerted collective action. And indeed, in absence of any regional leadership either by individual countries or regional organisation, predictably, each member must decide to fend for 
itself, consequentially fulfilling the realist prophecy of self-help. If regional organisations are not able to timely and effectively respond to such crisis, national self-help dynamics multiply. In consequence, realist predictions on COVID-19 (Walt 2020) were not only initially correct but are a self-fulfilling prophecy. In the absence of coordinated collective action and leadership by larger member states, unilateral self-help dynamics spread across membership like the communicable disease itself.

\section{Overcoming realism vicious cycle: regionalism's comeback}

All this is not to deny the legitimacy or urgency of national responses. Safeguarding citizens' security remains the most fundamental state task (Jean 1998). But pandemics are by definition a case for in international operation and failing to meaningfully coordinate a coherent regional response across membership raises doubts as to ASEAN's and EU's value-added in times of crises. But regionalism also offers a way out of the crisis. What is needed is a two-dimensional EU-ASEAN interregionalist approach: ASEAN should be willing to look at how the EU awoke from its initial paralysis and, as of yet, successfully addresses COVID-19. And secondly, the EU and ASEAN should cooperate more deeply on pandemics.

With their long inter-regional history, there should be sufficient inter-regional trust and mechanisms to meet both dimensions.

\section{Different logics of regionalism: natural partners?}

Both the EU and ASEAN are also outward oriented organisations. The EU's Global Strategy for European Foreign and Security Policy (EEAS 2016) specifically seeks global strategic relevance and meaningful global partnerships for a globally increasingly engaged EU. At the same time, in combination with the Treaty of Lisbon, all EU foreign policy is obliged to promote European values, norms and principles, such as democracy, human rights, good-governance and rule of law. As a result, the EU has become a pro-active, globally engaged normative power (Manners 2002) that seeks to diffuse its own ideas of regional integration and its basic principles (Börzel and Risse 2009; Smith 2008). Beyond the immediate neighbourhood, where the prospect of EU accession acts as a powerful incentive to adapt to EU norms, it is plausible that the EU can exercise its normative influence best vis-à-vis actors of a similar nature, i.e. other regional organisations like ASEAN, where the EU sees itself as model for regional integration - if not as model to be directly copied, at least as a reference point on how to achieve peace, stability and development.

ASEAN has from the beginning been an outward-oriented organisation, seeking to establish ties with all key actors in order to secure the interests of its comparatively small, anti-communist members (Mahbubani and Sng 2017). The EU, then called European Economic Community, became ASEAN's first dialogue partner in 1977, after informal dialogues had been taking place since 1972. Inter-regionalism deepened with a formal Cooperation Agreement. Although this agreement highlighted that this cooperation was one between equal partners (ASEAN 1980), ASEAN had always been a target for the EU's normative approach to inter-regionalism, seeking to influence ASEAN in its own image. Despite a temporary drop in engagement following ASEAN's membership 
expansion in the 1990s, the EU considers ASEAN a 'natural partner' and, over time, the inter-regional agenda broadened substantially. In 2007, the two sides adopted the Nuremberg Declaration on EU-ASEAN Enhanced Partnership, to which plenty of action plans followed, with the ASEAN-EU Plan of Action 2018-2022 being the most recent (ASEAN 2017). On 8 August 2015 (ASEAN Day), the EU established a diplomatic Mission to ASEAN and appointed an EU Ambassador to ASEAN.

The relationship now includes economics and trade, social-cultural and development cooperation, and more recently also political and security issues and challenges. Brussels openly supports the ASEAN-led multilateral regional architecture and is represented in some ASEAN-led forums, such as the ASEAN Regional Forum (ARF) and signatory to the important regional peace regime, ASEAN's Treaty of Amity and Cooperation (TAC). In 2015, the High Representative for Foreign Affairs and Security Policy, Federica Mogherini, voiced plans to forge a strategic partnership with ASEAN, with the aim of joining the East Asia Summit (EAS) and achieving observer status of ASEAN Defence Ministers' Meeting Plus (ADMM-Plus) Experts Working Group activities. The EU also actively seeks to become ASEAN's 'strategic partner', although the plan for a strategic partnership has not been met with great enthusiasm on the ASEAN side and is on hold indefinitely. The EU has been showing particularly strong interest in increasing NTS cooperation with ASEAN, a field in which the EU sees its competitive advantage.

Brussels rightly regards its regional integration process as largely successful and a model to take note of. Hence, from the EU perspective, the main objective of interregionalist engagement with ASEAN is managing complex interdependence (Keohane and Nye 2001), mutual economic gain and a greater responsibility for regional security. But also a constructivist understanding of cooperation whereby EU-ASEAN cooperation would cause the diffusion of EU norms, such as democracy and human rights within ASEAN (Jetschke and Murray 2012; Finnemore and Sikkink 1998).

The main tools to achieve such objectives are political dialogue mechanisms and intra-regional economic and political cooperation. It relies mostly on diplomacy via its ever-widening network of European diplomats in the region, economic incentives, such as free-trade agreements (FTA) or otherwise preferential trade, and financial and technical assistance. In addition to the EU Mission to ASEAN, there are currently 25 Ambassadors from individual EU countries accredited to ASEAN as well as a number of EU Missions to individual ASEAN member states. It is important to note that interregionalism as EU engagement with the ASEAN Secretariat or the rotating ASEAN presidency and vice versa does not function in isolation but is complemented by, and dependent on, the functioning of bilateral relations and EU relations with individual ASEAN members (Camroux 2010). The EU has, for example, two bilateral free-trade agreements with individual ASEAN member states (Singapore and Vietnam). Most importantly, the EU is actively funding ASEAN integration with various capacity building programmes and substantial funding. With broad support exceeding EUR200 million from 2014 to 2020, the EU is the single largest donor to the ASEAN integration project, contributing more to ASEAN integration than individual ASEAN members themselves. Despite the ritualistic refusal to see the EU as a model, European financial and capacity building support is very welcomed in ASEAN; indeed, it is necessary to keep the ASEAN project in its current form operational. ${ }^{1}$

\footnotetext{
$\overline{{ }^{1} \text { Several interviews with ASEAN }}$ bureaucrats in Jakarta, December 2015.
} 
For the time being, the EU has not fully convinced ASEAN that it can add value to regional security. ASEAN's interest in the EU remains predominantly motivated by economic interest, although ASEAN takes note of continued EU interest to play a greater security role (see ASEAN 2020c). Generally, among many ASEAN leaders and bureaucrats, the European experience is mostly of relevance in the sense that it shows the direction where a unique, much more diverse ASEAN ought not go. ASEAN elites have, thus, always purposefully avoided likening themselves to the EU model in any way, determined to go another way (Natalegawa 2015, p. 58f) and, at least publicly, ritualistically refuse to look to the EU as a model.

The gap in perceptions is due to different logics of regionalism in Europe and Southeast Asia. European regionalism is built on the need to overcome historically conflictual nationalism by integrating the regional economies so as to substantially increase the cost of future conflict. The EU's logic of regionalism can be summed up in the 1957 Treaty of Rome preamble's phrase 'ever closer union'. Ever closer union is symbolic for the principle idea underpinning European integration: nation states overcoming an absolutist interpretation of national sovereignty, with a gradually increasing supranationalism concentrated in Brussels. ASEAN's raison d'être, and in consequence its organisational structure, were always very different. Southeast Asia integration was always about 'continuous national development' and members' 'stability and security from external interference in any form in order to preserve their national identities' (ASEAN 1967). If ever closer union symbolises Europe's logic of regionalism, ASEAN's corresponding logic is encapsulated in the dichotomy of 'national and regional resilience'. If the nation state is robust, administered by a strong government and buoyed by sound economic growth and characterised by social harmony and a strong sense of nationalism and national belonging, it is better equipped to deal with outside threats. Inapprehensive of external interreference in domestic affairs, national governments can be stable and prosperous. Most ASEAN elites, not quite altruistically, see the other members' domestic stability as a non-negotiable, fundamental principle of regional integration. Paraphrasing Jusuf Wanandi, if each constituent part is strong, the chain will also be strong (quoted in Acharya 2014). The organisational result is the socalled ASEAN way, which remains ASEAN's blueprint for all internal and external political and security cooperation. ASEAN's modus operandi stands in stark contrast to the EU's legalistic and deeply institutionalised regionalism, prioritising inter alia sovereign equality and non-interference (Haacke 2003).

\section{Restoring trust-the great European recovery}

Prior to COVID-19, the extent of Brussels' institutional failure and lack of European cooperation would have been difficult to imagine. While it is impossible to foresee the long-term damage of this paralysis to the EU in general, it is encouraging to witness the EU's awakening and evident recovered, as the EU is engaging in impressively proactive pandemic management. Its lobbying efforts managed to break the negative selfhelp spiral across membership, as individual EU members stepped up their solidarity efforts, fearing reputational loss and irreparable damage to the EU. Following the woeful silence on Italy's CPM requests in February, in April, EU members commenced mutual support. Membership provided mutual consular support and repatriation of each other's citizens from third countries. EU Medical Corps facilitated the secondment of 
EU-wide medical experts to support pressured healthcare systems. Countries such as Germany and Austria opened their ICUs to other EU patients in critical condition. Others sent teams of medical doctors to support treatment of patients in Italian hospitals, while Denmark sent ventilators and field hospital equipment.

Financially, the renewed EU effort is at first sight very impressive. Initially, COVID19 seemed to resurface the cleavage of the 2010 Eurozone sovereign debt crisis with the request and subsequent disagreement over Coronabonds. But the EU Commission initiated a package worth EUR540 billion to support the worst affected EU businesses and workers and is rolling out a temporary assistance instrument (SURE) of up to EUR100 billion to mitigate rising unemployment and the European Central Bank provided a total of EUR870 billion to local banks. Most importantly, the EU Commission introduced the biggest financial EU instrument to date, finalised and duly approved in the European Council in the third quarter of 2020. The humongous European recovery instrument, NextGenerationEU, consists of a remarkable EUR750 billion in form of grants and loans and is to be independently raised by the EU on the financial markets. This amounts to nothing less but a transformation of EU fiscal policy, long opposed within the Eurozone. It is important to note, however, that there was substantial disagreement among Eurozone members and the initial Commission proposal had to be revised and amended mostly as a result of pressure exerted by the so-called frugal four, an informal grouping of some fiscally conservative countries, including Austria, Denmark, the Netherlands and Sweden. NextGenerationEU was, politically cunning, connected to the EU's regular 7-year budget, the Multiannual Financial Framework 2021-2027, which was due to be finalised in 2020 regardless of COVID-19. The coupled long-term budget and the temporary recovery instruments are the largest stimulus package ever financed through the EU budget and sum up to a total of EUR1.8 trillion. At the time of writing, the recovery fund has not yet been released due to disagreements among some EU members unrelated to COVID-19.

Perhaps most important for regionalism from a macro-perspective, however, is the EU's Joint Roadmap (EU Commission 2020c). This is to lift those pandemic management measures, such as border closures and export bans, that were being installed too hastily and uncoordinated, damaging European trust in EU regionalism and initiating the downward spiral of self-help mechanisms across membership. The 15-page roadmap is a detailed plan to regionally coordinate the gradual rollback of confinement measures and the resumption of proper regional procedure for post-COVID-19 recovery. With this, the EU initiated multi-sectoral ministerial coordination in order to jointly and coherently emerge from COVID-19 as one EU. It includes coordination on due procedure to gradually restore free movement within the EU, mutual healthcare support, resumption and maintenance of supply routes and transport infrastructure, and even the restart of sport activities and events. Importantly, for both practical reasons and as a gesture to regionalism, national ministers agreed to let the Commission lead this process.

The eventually produced roadmap is also the best answer the EU could have given to critics who already predicted the EU's downfall (Chrysoloras 2020; Caldwell 2020). In both ASEAN and the EU, decades of regional integration and historical reconciliation processes have created a certain degree of trust (Mayer 2015). This is reflected, for instance, in the establishment of nascent and mature security communities in the respective regions (Acharya 2014; Deutsch et al. 1957). However, the initial self-help 
reactions in both regions demonstrate how easily trust can fail and initiate the selffulfilling prophecy of realism. In order to not fall into this, member states need to have trust in each other. Trust and regionalism are mutually reinforcing social processes. Mayer (2015, p. 54) points out that trust is a necessary condition and a driver for regional integration. Trust facilitates cooperation but cooperation also promotes further trust (Putnam 1993, p. 171). Hence, any adversity must be followed by reconciliation. In order to restore trust in the mutually dependent constituents of regionalism and cooperation, it is imperative to not only invest financially in post-COVID-19 recovery but also to jointly discuss and coordinate an exit strategy from those unilaterally imposed restrictive measures that have hurt regional trust and initiated the viscous cycle of realism in the first place. And the EU has produced an exemplary blueprint.

\section{Inter-regional learning}

Although ASEAN leaders and the current ASEAN Chair all realise that COVID-19 is posing a serious challenge, ASEAN has yet to respond forcefully. The 2020 ASEAN Chair Vietnam sees much of its chairmanship plans derailed (Kliem 2020a, b) but is trying to facilitate regional coordination as much as possible. Hanoi hosted a special virtual ASEAN summit on 14 April to develop a COVID-19 strategy for the region (ASEAN 2020d). The summit allowed ASEAN leaders to learn about individual responses and reach agreement on a 'whole-of-ASEAN community approach' to combat the virus. This included the inauguration of a common COVID-19 ASEAN Response Fund and in-principle consensus on the need to address the situation on the frontline with joint procurement of medical supplies and stockpiling. ASEAN leaders also agreed to extensive sharing of information and best practices. On their recommendation, a virtual ASEAN Defence Senior Officials' Meeting (ADSOM) took place on 15 May to discuss, among other things, the ASEAN Center of Military Medicine (ACMM) as a suitable platform for table-top exercises on COVID-19 responses and pandemic preparedness in general. More immediate is the initiation of joint crossborder responses to retain the smooth functioning and openness of essential supply chains and trade routes to protect food security and the exchange of medical equipment.

Alas, much of these agreements remain on paper. Brussels on the other hand has implemented a coherent tangible approach to COVID-19 management and there is plenty ASEAN could study for lesson-drawing. Despite the habitual refusal to treat the EU as a model, two essential preconditions for successful inter-regional exchange are in place: communication mechanisms and precedents of institutional learning. In addition to plenty of inter-regional and bilateral diplomatic engagement, the latest EU funding cycle saw the launch of two inter-regional flagship programmes: The Enhanced ASEAN Regional Integration Support from the EU (ARISE Plus), which alone channels over $€ 90$ million towards ASEAN economic and trade integration, and the Enhanced Regional EU-ASEAN Dialogue Instrument (E-READI). E-READI, in 2017 succeeding its predecessor READI, supports EU-ASEAN network building and the exchange of experiences and best practices, whereby ASEAN is de facto meant to learn from the European integration process.

Much of the inter-regional policy and norm diffusion literature agrees that crises are oftentimes a driver of policy adaptation by lesson-drawing (Jetschke and Murray 2012; Börzel and Risse 2012). Indeed, Yeo (2008, p. 93) points out that frequent interactions 
with and the assistance provided by the EU have tangibly influenced the ASEAN internal discourse. And evidence suggests that this influence goes much further than discourse alone. For example, EU funded projects have influenced and changed ASEAN standards and practices and synchronised ASEAN with EU norms on matters such as intellectual property rights (Dosch 2018, p. 185). In particular in the economic realm, ASEAN has looked to the European experience, not to use the single market as a blueprint but to borrow ideas for own economic integration within the ASEAN Economic Community (AEC). Similarly, the 2007/08 ASEAN Charter draws heavily on EU concepts and terminology (Börzel and Risse 2009). The Charter gave ASEAN a legal personality and built a formal dispute settlement procedure, which was influenced by European practices. Two chairpersons of the High-Level Task Force for the drafting of the ASEAN Charter recall that there was a strong European learning process, including study visits to Brussels (Koh et al. 2009, p. 14, 41, 76f). The Charter also strengthened the capacity of the ASEAN Secretariat and the Secretary-General, and there are frequent calls to go even further-not to develop it into an EU Commission but to allow it to meaningfully coordinate and monitor ASEAN decisions.

$\mathrm{Al}$ this is not at all to suggest that ASEAN should imitate the EU or even see it as model to move towards. It is neither the intent here nor feasible to suggest ASEAN reform to radically change the ASEAN way or to provide the Secretariat with substantial independent authority. Nor is the intent to suggest that the EU should be a general blueprint. The EU is in constant crisis modus for over a decade now due to its own shortcomings. And the unique European history precipitating integration means that one should be careful about extrapolating from the EU's experience or even assuming the EU represents a model for other regions (Beeson 2003). Neither is inter-regional policy-learning nor lesson-drawing one-dimensional. It is indeed a two-way process of communication. But in the particular case of COVID-19, the EU's eventual reaction has been precisely what ASEAN leaders identified as their intended approach: a caring multi-stakeholder whole-of-community approach (ASEAN 2020d) — and there is plenty of room for lesson-drawing - one-way, in this specific case. Hence, instead of looking as the EU as a 'policy-entrepreneur' and ASEAN as a 'passive policyrecipient', it is helpful to consult Amitav Acharya's 'norm-localisation' concept. Acharya argues that the continuation of the specific ASEAN way and the particular local norms that underpin it are imperative to ASEAN's continued success (Acharya 2007, p. 15). But, as Acharya concedes, in its foundational principles, the uniquely Southeast Asian form of regionalism to some extent follows certain well-established international principles as documented for instance in the UN Charter or the 1955 Bandung Conference. With this in mind, Acharya's (2009) 'norm localization' concept is very helpful in understanding that policy-learning, as suggested here in this article, is not simple policy imitation, but a form of realistic, pro-active best-practice adaptation. Acharya's ground-breaking study (2009) shifts the focus from 'norm-entrepreneurs', or norm-shapers, towards the indeed very important role of 'norm-recipients' (Rüland 2014, p. 239). Instead of simply being passive norm-takers, the role of the receiving agent becomes much more pro-active. Acharya convincingly demonstrates how norm acceptance comes with substantial agency on the part of the recipient: The ability of local agents to reconstruct external norms to match their local 'cognitive priors', preexisting identities. Foreign norms, Acharya argues, are more likely to be adopted if congruent with the pre-existing normative order in the region of the recipients. Local 
agents, therefore, are not passive norm-takers simply accepting or rejecting norms but instead localise norms as they see fit by assessing, reconstructing and even extending foreign norms in order to fit local contexts. Such a process of norm localisation is highly relevant here, for it helps to understand the substantial agency ASEAN has when studying the EU's approach to COVID-19. Specific EU policies and utilisation of EU mechanisms for pandemic management should be assessed for their efficacy in the light of local Southeast Asian conditions, i.e. ASEAN's degree of institutionalisation as well as potential acceptance on the national level. Just like norms can, and indeed must be localised, lesson-drawing and policy-learning must be a much more complex process of pro-active localisation, too.

The final two questions left to be addressed in this paper are what exact EU measures ASEAN should look at for potential lesson-drawing and what can both organisations do together?

All reasonable lesson-drawing results suggested below can tap into existing ASEAN mechanisms for managing natural disasters and do not require the EU's integrational depth. ASEAN should leverage its plethora of existing mechanisms and frameworks, by increasing the capacity of existing instruments to better account for the threats of pandemics. Any policy orientation should - and de facto would - take place under due consideration of local contexts - quite in line with Acharya's localisation concept, whereby foreign norm or policy imports are assessed, declared appropriate or inappropriate, amended as required and implemented - all in agreement of local conditions.

It is unreasonable to expect ASEAN to produce a region-wide bailout package like the EU did. However, the ASEAN Rescue Fund is a step in the right direction, albeit a likely too small amount. Importantly, ASEAN has secured buy-in from its ASEAN Plus-Three (APT) partners, Japan, South Korea and China, to contribute to the fund by re-prioritising and reallocating the substantial existing cooperation funds. This needs to be extended onto the ASEAN-EU agenda, too, where ASEAN is likely to find a further generous partner. Indeed, the first EU-ASEAN Meeting on COVID-19 on 20 March agreed to deepen cooperation. The EU already committed a total of EUR350-400 million to support ASEAN members with a wide variety of programmes to address the immediate health crisis and prevent further spread as well as mitigate the social and economic consequences of the pandemic. ${ }^{2}$

Second, ASEAN should study how the ECDC collaborates closely with the corresponding member states' bodies across Europe to strengthen EU-wide surveillance and early warning. ECDC pools Europe's health information to develop advisories on the current and emerging diseases and provides information to members and the Commission. The ECDC also facilitates European public health networking and activities to exchange information and best practices. While ASEAN has a number of response mechanisms in place, such as a Network for Public Health Emergencies or the ASEAN Risk Assessment and Risk Communication Centre, it appears that those mechanisms have been comparatively mute due to a sovereign-conscious ASEAN way. Much more can be done by leveraging these and other existing mechanisms in Southeast Asia. In the near future, the EU Mission to ASEAN will host a series of webinars, which will

\footnotetext{
${ }^{2}$ This effort is part of EU's 'Team Europe' package to support partner countries pandemic and recovery management with more than EUR20 billion.
} 
support the exchange of experiences and practices agreed on at the EU-ASEAN Meeting on COVID-19.

Third, while individual ASEAN members have provided consular support to each other, the pandemic brutally exposed the healthcare capacity gap across ASEAN. Singapore rolled out mass-testing, isolated its foreign worker community and substantially increased its already exemplary ICU capacity. Meanwhile, the inadequacy of healthcare systems in other countries required third-party assistance to address nationwide contagion. ASEAN should assume a role in immediate pressure relief for lesserdeveloped healthcare systems that are not sufficiently equipped to fight pandemics. Singapore is Southeast Asia's medical centre of excellence and has 2.5 physicians per 1000 people, whereas Laos has only 0.5. Again, in interconnected regions, pandemic resilience is only as strong as its weakest national link and the weakness of one member's healthcare system is also the weakness of another's. Yet, a temporary secondment of doctors and health experts across ASEAN in response to pandemics does not take place in a meaningful way. ASEAN could look towards Europe to evaluate to what extent the sending of medical teams and mutual treatment of each other's citizens can be implemented. One can foresee a strong facilitating role for ACMM.

Fourth, ASEAN should consider having a joint stockpile of essential medical products. Just like the EU's 'rescEU reserve' mechanism, which is compiling a European reserve of resources, including a stockpile of medical equipment and field hospitals that can respond to health emergencies. ASEAN must also jointly procure and stockpile medical equipment for pandemic management, store it in jointly managed warehouses under the auspices of the ASEAN Centre for Humanitarian Assistance on Disaster Management (AHA centre) and distribute via existing emergency instruments, such Disaster Emergency Logistics System for ASEAN (DELSA), quickly if and when and to wherever necessary. This does not require any substantial change to existing mechanisms, but only capacity strengthening and widening of scope of the AHA centre and DELSA. In combination, they fulfil a similar function of 'rescEU reserve' and the EU's Emergency Response Coordination Centre (ERCC), which coordinates the delivery of reserves. The AHA centre, in fact, should become ASEAN's first responder. This would reduce the need to rely on third parties to address members' most immediate needs, thereby preventing further entrenchment of already existing dependencies of some ASEAN members on particularly China, whose track record on ASEAN unity is not good.

Most important, however, is a close look at the EU's roadmap. According to the above analysis of regional cooperation, trust is a necessary constituent of successful regionalism and in order to escape the national self-help cycle, it is imperative that ASEAN look towards the EU's roadmap and the process to ease restrictive measures jointly and cooperatively, across all sectors and facilitated by a coordinating authority. Despite differing national conditions, action must be coordinated between member states to avoid political friction and reinstall trust. Mutual respect and intra-mural solidarity are essential. Any solution should be based on science and balance social and economic elements. ASEAN will be able to cooperate closely with ECDC to this end. There has been some commendable bilateral intra-ASEAN precedent that follows such an approach and should be gradually extended to include all of membership. Since Malaysia's initial restrictions caused substantial problems in Singapore, the two 
countries have established a special working committee to manage any complications caused by respective lockdown measures and to coordinate a joint mitigation plan to ensure the safe and sustainable movement of people, goods and services between Malaysia and Singapore.

Such eventual dialogue on collaborative lifting of measures must also result in common guidelines for implementation of pandemic responses in the future. This minimises the detrimental impact on supply chains, trade and free movement. But more importantly, it can help to prevent or mitigate the negative dynamics of unilateralism and restore trust in regionalism's value-added.

\section{Conclusion}

This paper showed the causal relationship between robust unilateral national responses to COVID-19 as a result of securitisation and the inefficacy of regional organisations. If governments switch into full nationalist gear, leaving regional organisations behind, there is a strong incentive for others to do the same. However, regional cooperation requires trust. The self-fulfilling prophecy of realism in times of acute crises can be overcome only if members have trust in the willingness of especially larger members states to cooperate jointly within the regional organisation framework. To elicit such positive-sum dynamics, there needs to be sound communication to coordinate and synergise national crisis management strategies.

Initial apathy has undoubtably caused some reputational and institutional damage in both regions, but this need not last if both organisations manage to leverage existing mechanisms and create a trust surplus. The negative impact on regionalism in Southeast Asia may be less severe than on the EU. Mostly due to lower expectations and capacity ASEAN sometimes struggles to effectively address NTS challenges (Caballero-Anthony and Gong 2020). But COVID-19 provides ASEAN with a unique opportunity to demonstrate its collective care for each other and its ambition for a people-centred ASEAN. Despite initial crisis paralysis, the EU has since taken extraordinarily proactive measures to manage COVID-19 and there are lessons to be learnt and institutional momentum is building. The EU has been strongly supportive of both ASEAN integration and inter-regionalism, and despite limitations as a result of different logics of regionalism, this paper has demonstrated that past and current EU-ASEAN programmes can facilitate impactful inter-regional lesson-drawing.

A collaborative pandemic management strategy in ASEAN does not require substantial institutional change, but expanding and exhausting existing mechanisms and partnerships. Leveraging existing mechanisms needs sound regional cooperation which will spill-over trust and can result in strengthened regional institutions and mechanisms. In preparation for the presidency of the Council of the European Union German Chancellor Angela Merkel articulated her ambition to ensure that the EU will emerge from the pandemic stronger than it went into it, for which European solidarity was imperative. The Chancellor also highlighted that is was equally important to build on Europe's reputation as a reliable partner for others and assume greater responsibilities for its partners (KAS 2020). Notwithstanding critiques of ASEAN being a talk shop (Jones and Smith 2007), previous crises show that ASEAN can mobilise forces and incubate closer cooperation just like Europe. If these experiences are anything to go by, 
then COVID-19 with its serious consequences for the livelihoods and health of ASEAN peoples and the economies of ASEAN states will prove to be another important juncture of growth for ASEAN solidarity and integration.

The dreadful devastation of COVID-19 is a unique opportunity to propel regionalism in Asia and Europe to new heights and to increase inter-regional cooperation between the two regional organisations. Achieving this would directly advance both regional organisations' visions for greater political, security and social community. For the EU, supporting and collaborating with ASEAN on COVID-19 and NTS in general lives up to the objectives stated in the Global Strategy for the European Union's Foreign and Security Policy and its ambition to achieve security relevance in Asia. For ASEAN, leveraging the strong EU relationship will support its pandemic management efforts and thereby directly demonstrate its relevance in Southeast Asia and support its ASEAN Community vision. Effective pandemic management and interregional cooperation with Europe as well as bilateral cooperation with individual nonASEAN countries will reinforce ASEAN centrality by evidencing ASEAN's relevance to regional security governance.

It will take a large amount of effort and political will for the world's two most sophisticated regional organisations to emerge from this pandemic unscathed, let alone strengthened. But if the EU and ASEAN manage to capitalise on this momentum, there is a real chance that history will remember COVID-19 as a driver of regional cooperation in Europe and Southeast Asia and both organisations will emerge stronger from than pandemic than they went into it.

\section{References}

Acharya A (2007) Theoretical perspectives on international relations in Asia. Draft Paper for the Conference on International Relations in Asia: The New Regional System. George Washington University, 27-29 September 2007).

Acharya A (2009) Whose ideas matter: agency and power in Asian regionalism. Cornell University Press, Ithaca

Acharya A (2014) Constructing a security community in Southeast Asia: ASEAN and the problem of regional order, 3rd edn. Routledge, London

ASEAN (1967). ASEAN Declaration. https://asean.org/the-asean-declaration-bangkok-declaration-bangkok8-august-1967/.

ASEAN (1980). Cooperation agreement between member countries of ASEAN and European community Kuala Lumpur. https://asean.org/?static_post=external-relations-european-union-nuremberg-declarationon-an-eu-asean-enhanced-partnership-nuremberg-germany-15-march-2007.

ASEAN (2017). ASEAN-EU plan of action (2018-2022). https://asean.org/storage/2017/08/ASEAN-EUPOA-2018-2022-Final.pdf.

ASEAN (2020a) Economic impact of COVID-19 outbreak on ASEAN. https://asean.org/storage/2020/04/ ASEAN-Policy-Brief-April-2020_FINAL.pdf.

ASEAN (2020b) Declaration of the Special ASEAN Summit on Coronavirus Disease 2019. https://asean.org/ storage/2020/04/FINAL-Declaration-of-the-Special-ASEAN-Summit-on-COVID-19.pdf.

ASEAN (2020c) Joint Press Statement, 27th ASEAN-EU Joint Cooperation Committee (JCC) Meeting, Jakarta. https://asean.org/storage/2020/03/27th-ASEAN-EU-JCC-Joint-Press-Statement_final.pdf.

ASEAN Today (2020) ASEAN has failed to cooperate on COVID-19, leaving marginalized groups exposed. https:/www.aseantoday.com/2020/04/asean-has-failed-to-cooperate-on-covid-19-leaving-marginalizedgroups-exposed/. 
Beeson M (2003) Sovereignty under siege: globalisation and the state in Southeast Asia. Third World Q 24: 357-374

Booth K (2005) Critical security studies and world politics. Lynne Rienner, Boulder

Börzel T \& Risse T (2009) Diffusing (inter-) regionalism: the EU as a model of regional integration. KFG Working Paper Series No 7, The Transformative Power of Europe, Freie Universität Berlin

Börzel T, Risse T (2012) From Europeanisation to diffusion: introduction. West Eur Polit 35(1):1-19

Caballero-Anthony M (2018) Negotiating governance on non-traditional security in Southeast Asia and beyond. Columbia University Press, New York

Caballero-Anthony M, Gong L (2020) Non-traditional security issues in ASEAN: agendas for action. ISEAS Publishing, Singapore

Caldwell C (2020) Can the European Union survive a pandemic? The New Republic. https://newrepublic. com/article/157579/can-european-union-survive-coronavirus-pandemic.

Camroux D (2010) Interregionalism or merely a fourth-level game? An examination of the EU-ASEAN relationship. East Asia 27:57-77

Chong A, \& Kliem F. (2020) Global Health Security: COVID-19 and its impact-EU and ASEAN: in common disunity. RSIS Commentary. https://www.rsis.edu.sg/rsis-publication/cms/global-healthsecurity-covid-19-and-its-impact-eu-and-asean-in-common-disunity/\#.XvWipS2Q3OQ. .

Chrysoloras N (2020) Debt crisis, Brexit, now virus. Can the EU survive? Bloomberg. https://www. bloomberg.com/news/articles/2020-05-13/how-the-virus-poses-an-existential-threat-to-the-eu-quicktake.

Deutsch K et al (1957) Political community and the North Atlantic area: international organization in the light of historical experience. Princeton University Press, Princeton

Dosch J (2018) The EU and the Asia-Pacific. In Connors/Davison/Dosch. In: The New Global Politics of the Asia-Pacific, 3rd edn. Routledge, London

EEAS-European External Action Service (2016) Shared vision, common action: a stronger Europe. A Global Strategy for the European Union's Foreign And Security Policy. http://eeas.europa.eu/archives/docs/top_ stories/pdf/eugs_review_web.pdf.

EU Commission (2020a) Frühjahrsprognose 2020. https://ec.europa.eu/commission/presscorner/detail/de/ip_ 20799.

EU Commission (2020b) Speech by President at the European Parliament of 26 March. https://ec.europa.eu/ commission/presscorner/detail/en/SPEECH_20_532.

EU Commission (2020c) Joint European Roadmap towards lifting COVID-19 containment measures. https:// ec.europa.eu/info/sites/info/files/communication_-_a_european_roadmap_to_lifting_coronavirus_ containment measures 0.pdf.

European Centre for Disease Control (2020) Rapid risk assessment. https://www.ecdc.europa.eu/en/ publications-data/rapid-risk-assessment-outbreak-novel-coronavirus-disease-2019-covid-19-increased.

Finnemore M, Sikkink K (1998) International norm dynamics and political change. Int Organ 52(4):887-917

Haacke J (2003) ASEAN's diplomatic and security culture: a constructivist assessment. Int Relat Asia-Pac 3(1):57-87

Hayton B \& Tro Ly Ngheo (2020). Vietnam's coronavirus success is built on repression. Foreign Policy. https://foreignpolicy.com/2020/05/12/vietnam-coronavirus-pandemic-success-repression/.

Herszenhorn DM \& Wheaton S (2020) How Europe failed the coronavirus test. Politico. https://www.politico. eu/article/coronavirus-europe-failed-the-test/.

Horowitz J (2020) Italy's health care system groans under coronavirus - a warning to the world. New York Times, 12 March.

Jean C (1998) The role of the nation state in providing security in a changed world. Int Spectator 33(1):67-77

Jetschke A, Murray P (2012) Diffusing regional integration. The EU and Southeast Asia. West Eur Polit 35(1): 174-191

Jones D, Smith M (2007) Making process, not progress: ASEAN and the Evolving East Asian Regional Order. Int Secur 32(1):148-184

Keohane R, Martin L (1995) The promise of institutionalist theory. Int Secur 20(1):42

Keohane R, Nye J (2001) Power and interdependence: world politics in transition, 3rd edn. Longman, New York

Khmer Times (2020) Kingdom closes border with Vietnam over outbreak. https://www.khmertimeskh.com/ 703485/kingdom-closes-border-with-vietnam-over-outbreak/. .

Kliem F (2020a) Coronabonds: backdoor to collective debt? RSIS Commentary. https://www.rsis.edu.sg/rsispublication/cms/global-health-security-coronabonds-backdoor-to-collective-debt/\#.XuxV7i2Q3UI. .

Kliem F (2020b) Vietnam's ASEAN Chairmanship 2020: what to expect. RSIS Commentary. https://www. rsis.edu.sg/rsis-publication/cms/vietnams-asean-chairmanship-2020-what-to-expect/\#.XuHCmi17HOQ. . 
Koh T, Rosario E, Woon W (2009) The making of the ASEAN charter. World Scientific Publishing, Singapore

Konrad-Adenauer Stiftung (2020) Europa als solidarische, handlungsfähige und gestaltende Kraft weiterentwickeln. https://www.kas.de/de/veranstaltungsberichte/detail/-/content/europa-als-solidarischehandlungsfaehige-und-gestaltende-kraft-weiterentwickeln. (in German)

Mahbubani K, Sng J (2017) The ASEAN miracle. A catalyst for peace. Ridge Books, Singapore

Manners I (2002) Normative power Europe: a contradiction in terms? J Common Mark Stud 20(2):235-258

Mayer H (2015) Historical narratives as normative drivers of integration and disintegration in Europe and Asia. In: Brennan L, Murray P (eds) Drivers of integration and regionalism in Europe and Asia: comparative perspectives. Routledge, London

Mearsheimer J (1995) The false promise of international institutions. Int Secur 19(3):5-49

Momtaz R (2020) Inside Macron's coronavirus war. Politico. https://www.politico.eu/interactive/insideemmanuel-macron-coronavirus-war/. .

Mügge L (2016) Transnationalism as a research paradigm and its relevance for integration. In: GarcésMascareñas B, Penninx R (eds) Integration processes and policies in Europe. IMISCOE Research Series. Springer, Cham

Natalegawa M (2015) Does ASEAN matter? A view from within. ISEAS Publishing, Singapore

Nguyen HK \& Ho TM (2020) Vietnam's COVID-19 strategy: mobilizing public compliance via accurate and credible communications, ISEAS Perspectives No. 69, https://www.iseas.edu.sg/wp-content/uploads/ 2020/05/ISEAS Perspective 2020 69.pdf. .

Putnam RD (1993) Making democracy work. Civic traditions in modern Italy. Princeton University Press, Princeton

Rüland J (2014) The limits of democratizing interest representation. ASEAN's regional corporatism and normative challenges. Euro J Int Relat 20(1):237-261

SG United (2020) https://www.sgunited.gov.sg. .

Smith K (2008) European Union Foreign Policy in a Changing World, 2nd. Cambridge University Press, Cambridge

UK Government (2020) Military stands up COVID support force. https:/www.gov.uk/government/news/ military-stands-up-covid-support-force.

UN Commission on Human Security (2003) Human security now: protecting and empowering people. https:// reliefweb.int/report/world/human-security-now-protecting-and-empowering-people.

Waever O (1995) Securitization and desecuritization. In: Lipschutz RD (ed) On security. Columbia University Press, New York

Walt SM (2020) The realist's guide to the coronavirus outbreak. Foreign Policy. https://foreignpolicy.com/ 2020/03/09/coronavirus-economy-globalization-virus-icu-realism/.

Waltz K (1979) Theory of international politics. McGraw-Hill, New York

World Economic Forum (2020) The next super bug|DAVOS 2020. https://www.youtube.com/watch? $\mathrm{v}=$ 4NXHw5Jf4 s.

Yeo LH (2008) EU-ASEAN relations and policy-learning. In: Balme B (ed) Europe-Asia relations. Palgrave Studies in European Union Politics. Palgrave Macmillan, London

Publisher's note Springer Nature remains neutral with regard to jurisdictional claims in published maps and institutional affiliations. 